\title{
Pra Desain Pabrik Lube Base Oil dari Oli Bekas dengan Proses Ekstraksi Solvent
}

\author{
Amirut Tahfifah, Hilda Dwi Lestari dan Setiyo Gunawan \\ Teknik Kimia, Fakultas Teknologi Industri, Institut Teknologi Sepuluh Nopember (ITS) \\ Jl. Arief Rahman Hakim, Surabaya 60111 Indonesia \\ e-mail: gunawan@chem-eng.its.ac.id
}

\begin{abstract}
Abstrak-Minyak pelumas dasar merupakan bahan baku dari pembuatan minyak pelumas atau oli yang digunakan untuk berbagai jenis permesinan baik berat maupun ringan. Sebagian besar pelumas terdiri dari lube base oil $80 \%$ dan $20 \%$ merupakan aditive. Minyak pelumas, baik yang berasal dari ekstraksi crude oil atau yang berasal dari minyak sintetis telah digunakan secara luas dalam dunia industri, dari proses pelumasan, transfer panas, metal cutting dan sebagainya. Dari proses pengaplikasian tersebut, minyak pelumas yang digunakan akan terkontaminasi dan atau terdegradasi. Minyak inilah yang selanjutnya disebut minyak pelumas bekas (used oil). Hal ini secara otomatis memunculkan permasalahan baru dengan hadirnya limbah minyak peIumas atau oli bekas yang sangat melimpah tersebut. sehingga akan berdampak bagi kesehatan dan lingkungan. Minyak pelumas bekas mengandung sejumlah zat yang bisa mengotori udara, tanah, dan air. Di Indonesia terdapat beberapa perusahaaan yang telah memproduksi minyak pelumas dari baik dari crude oil maupun dari oli bekas. Menurut Kemenperin (2008 - 2012), impor lube base oil ataupun minyak pelumas terus mengalami peningkatan. Melihat banyaknya penggunaan minyak pelumas bekas yang tersedia di Indonesia dan kebutuhan akan minyak pelumas yang semakin meningkat, maka direncanakan akan didirikan pabrik pengolohan lube base oil (minyak pelumas dasar) dari oli bekas. Selain untuk memenuhi kebutuhan, proses ini juga untuk mengurangi jumlah limbah oli bekas yang merupakan limbah B3. Terdapat beberapa proses pembuatan minyak pelumas dasar dari oli bekas ini, diantaranya proses hidrotreathing dan ekstraksi solvent. Pada proses hidrotreathing, minyak pelumas dasar dipisahkan dari fraksi unsaturated melalui reaksi hidrogenasi. Pada proses ini digunakan gas hidrogen. Sedangkan pada proses ekstraksi solvent, minyak pelumas bekas diekstraksi menggunakan pelarut organik untuk memisahkan fraksi minyak pelumas dasar dan unsaturated/sludge nya. Dari masing- masing proses tersebut, dapat dihasilkan produk samping yang juga bernilai ekonomi tinggi. Diantaranya adalah asphalt, fuel oil, dsb. Pabrik Minyak pelumas dasar direncanakan berdiri pada tahun 2019 yang berlokasi di Cilegon dengan kapasitas produksi adalah sebesar $30700 \mathrm{~kL} /$ tahun dengan menggunakan bahan baku Minyak pelumas bekas sebesar $54.101 .520 \quad \mathrm{~kg}$ /tahun, N-Metil-2-Pyrrolidone 69.068.471 kg/tahun, Larutan $\mathrm{NaOH} 48 \% 1.127 \mathrm{~kg} / \mathrm{tahun}$. Pabrik lube base oil ini direncanakan beroperasi secara kontinyu selama 24 jam dengan waktu produksi 330 hari/tahun. Operasi pabrik lube base oil ini memiliki perencanaan sebagai berikut: modal tetap (FCI) sebesar Rp. 72.968.078.246, modal kerja sebesar Rp. 12.876.719.692, investasi total (TCI) sebesar Rp. 85.844.797.937, Internal Rate of Return sebesar 46,7 \%, Pay Out Time sebesar 2,74 tahun, dan BEP sebesar $22,86 \%$
\end{abstract}

Kata Kunci-Ekstraksi Solvent, Oli bekas, Lube Base Oil, Analisa Ekonomi

\section{PENDAHULUAN}

$M$ INYAK pelumas,baik yang berasal dari ekstraksi crude oil atau yang berasal dari minyak sintetis telah digunakan secara luas dalam dunia industri, dari proses pelumasan, transfer panas, metal cutting dan sebagainya. Dari proses pengaplikasian tersebut, minyak pelumas yang digunakan akan terkontaminasi dan atau terdegradasi. Minyak inilah yang selanjutnya disebut minyak pelumas bekas (used oil). Hal ini secara otomatis memunculkan permasalahan baru dengan hadirnya limbah minyak peIumas atau oli bekas yang sangat melimpah tersebut. sehingga akan berdampak bagi kesehatan dan lingkungan.

Minyak pelumas bekas mengandung sejumlah zat yang bisa mengotori udara, tanah, dan air. Minyak pelumas bekas itu mungkin saja mengandung logam, larutan klorin, dan zat-zat pencemar lainnya. Apabila limbah minyak pelumas tumpah di tanah akan mempengaruhi air tanah dan akan berbahaya bagi lingkungan. Hal ini dikarenakan minyak pelumas bekas dapat menyebabkan tanah kehilangan unsur hara. Sedangkan sifatnya yang tidak dapat larut dalam air juga dapat membahayakan habitat air, selain itu juga memiliki sifat yang mudah terbakar yang merupakan karakteristik dari Bahan Berbahaya dan Beracun (B3).

Manajemen pengaturan minyak pelumas bekas sangat diperlukan, khususnya dalam dunia industri. Dalam kuantitas banyak, minyak pelumas bekas dapat direcycle dengan beberapa proses permunian, baik secara langsung maupun secara tidak langsung (melalui proses separasi dan refinement). Opsi pertama proses permunian adalah dengan mengembalikan original properties dari minyak pelumas tersebut. Opsi selanjutnya adalah dengan memperbaiki heating value dari minyak pelumas bekas tersebut. Setelah proses pemurnian tersebut, minyak pelumas bekas tersebut dapat digunakan sebagai lube base stock (base oil) atau sebagai burning fuel.

Pendirian pabrik pengolahan minyak pelumas bekas dapat Mengurangi daur ulang illegal yang prosesnya tidak bisa dipertanggungjawabkan. Daur ulang illegal menghasilkan pelumas-pelumas palsu yang kualitasnya tidak bisa dipertanggungjawabkan.

Disamping itu, pendirian pabrik pengolahan minyak pelumas bekas dapat menghemat devisa negara karena Indonesia bisa terhindar dari keharusan impor base oil atau impor minyak mentah untuk diolah menjadi base oil. Karena Indonesia tidak memiliki minyak mentah yang bisa diolah menjadi base oil. Untuk diketahui, kebutuhan pelumas di Indonesia mencapai 
800 juta liter per tahun. [19]

Meningkatnya penggunaan kendaraan bermotor serta mesin untuk kebutuhan industri saat ini memberikan dampak yang positif bagi industri pelumas. Karena adanya keterkaitan erat antara pemakaian kendaraan bermotor serta mesin untuk industri dengan pelumas, khususnya distributor pelumas di Indonesia. Berdasarkan data konsumsi Factfish Indonesia:Lubricants,consumption[17], pada tahun 2011 di Indonesia sebesar 4.189.138.200 metrik ton. Sedangkan data produksi lube base oil 1.148 .514 metric ton pertahun. Sehingga, kebutuhan pelumas di Indonesia hingga tahun 2011 belum terpenuhi. Dengan memanfaatkan oli bekas untuk diolah kembali menjadi bahan dasar pelumas diharapkan dapat memenuhi kebutuhan pelumas di Indonesia.

Setelah dikeluarkannya keputusan Menteri Perindustrian dan Perdagangan No.372/MPP/Kep/12/2001 dan Keputusan Menteri Energi dan Sumber Daya Mineral No.1693K/34/MEM/2001 tentang Ketentuan Pemberian Ijin Usaha Industri Pabrikasi Pelumas dan Pengelolaan Pelumas Bekas, sampai saat ini sekitar 35 perusahaan LOBP dengan kapasitas terpasang tidak kurang dari 700.000 kiloliter sudah mendapatkan izin usaha dan beroperasi juga melaksanakan jasa blending atau sebagai blender merek-merek lainnya.

Minyak pelumas dasar merupakan bahan baku dari pembuatan minyak pelumas/oli yang digunakan untuk berbagai jenis permesinan baik berat maupun ringan. Sebagian besar pelumas terdiri dari lube base oil $80 \%$ dan $20 \%$ merupakan aditive. Dari kondisi tersebut terlihat konsumsi minyak pelumas dasar di Indonesia cukup besar.

\section{II.URAIAN PROSES}

\section{A. Seleksi Proses}

Dalam perancangan pabrik Lube Base Oil perlu dilakukan seleksi proses. Seleksi proses bertujuan untuk mendapatkan hasil maksimal dari segi ekonomi maupun produk. Pembuatan lube base oil dapat dipilih dari proses ekstraksi solvent.

\section{B. Proses Produksi Lube Oil}

Proses pembuatan Lube base oil pada pabrik ini menggunakan proses ekstraksi solvent yang pada intinya adalah menghilangkan zat-zat pengotor dan kandungan sulfur pada oli bekas dengan mengontakkan oli bekas yang telah ditreatment dan pelarut N-methyl-2-Pyrrolidone. Proses pembuatan lube base oil dari oli bekas terdiri dari beberapa unit proses yaitu:

1. Dewatering Unit

2. Sludge Removal Unit

3. Extraction and Resircullation Unit

\section{C.Analisa Ekonomi}

Analisa ekonomu adalah salah satu parameter dilihat pabrik tersebut layak atau tidak untuk didirikan. Harga peralatan untuk proses berdasarkan neraca massa dan energy. Selain itu jumlah dan gaji karyawan serta pengadaan lahan untuk pabrik. Perhitungan Laju pengembalian modal (rate of return), waktu pengembalian modal (pay out time), titik impas (break event point), interest rate of return (IRR) ${ }^{[12]}$.

\section{HASILPERANCANGAN PABRIK LUBE OIL}

\section{A. Seleksi Proses}

Hal-hal yang perlu diperhatikan dalam pemilihan proses adalah dari segi proses pembuatan produk yang meliputi bahan baku, konversi reaksi, kuantitas produk dan kualitas produk. Sedangkan dari kondisi operasi yaitu mengenai temperatur, tekanan operasi dan dari segi ekonomi yaitu mengenai investasi, ROI ( Return of Invesment) danjuga POT (Pay Out Time). Dari kriteria-kriteria dan uraian proses pengolahan oli bekas menjadi Lube Base Oil diatas dapat dilihat keuntungan dan kerugian dari masing-masing proses. Dipilih Proses Ekstraksi Solvent untuk pembuatan lube base oil dari oli bekas dengan pertimbangan kondisi operasi pada suhu dan tekanan yang tidak terlalu tinggi sehingga membutuhkan energi yang lebih sedikit dan tingkat korosi yang rendah sehingga biaya perawatan lebih murah. ${ }^{[10]}$

\section{B. Proses Produksi Lube Oil}

Bahan baku oli bekas didapatkan melalui pengepul oli bekas dan pihak pengumpul limbah B3 dengan spesifikasi seperti Tabel 1,Tabel 2, dan Tabel 3.

Tabel 1. Komposisi Bahan Baku ${ }^{[19]}$

\begin{tabular}{ll}
\hline \hline Komponen & w/w $(\%)$ \\
\hline Air & $: 0.07$ \\
Lube Oil & $: 0.61$ \\
PAH & $: 0.06$ \\
Gasoline & $: 0.01$ \\
Sulfur & $: 0.01$ \\
Unsaturated & $: 0.24$ \\
\hline \hline
\end{tabular}

Tabel 2. Komposisi Lube Oil ${ }^{[19]}$

\begin{tabular}{lcc}
\hline \multicolumn{1}{c}{ Komponen } & NBP $\left({ }^{\circ} \mathrm{C}\right)$ & Fraksi $(\mathrm{b} / \mathrm{b})$ \\
\hline n-octadecane & 317 & 0.03 \\
n-Nonadecane & 330 & 0.03 \\
n-Icosane & 342 & 0.03 \\
n-Heneicosane & 356 & 0.03 \\
n-tricosane & 379 & 0.04 \\
n-Tetracosane & 391 & 0.06 \\
n-pentacosane & 401 & 0.07 \\
n-Heptacosane & 422 & 0.17 \\
n-Nonacosane & $441^{\circ}$ & 0.37 \\
n-Dotriacontane & 466,7 & 0.18 \\
\hline \hline
\end{tabular}


Tabel 3. Komposisi PAH ${ }^{[19]}$

\begin{tabular}{lcc}
\hline \hline Komponen & $\begin{array}{c}\text { NBP } \\
\left({ }^{\circ} \mathrm{C}\right)\end{array}$ & Fraksi (b/b) \\
\hline naphtalene & 218 & 0.37 \\
acenaptalene & 276 & 0.63 \\
Total & & 1 \\
\hline \hline
\end{tabular}

Mekanisme pembuatan lube oil dengan proses ekstraksi solvent dilakukan dengan mengontakkan oli bekas yang telah ditreatment dengan pelarut N-Methyl Pirrolidone. Pertama,adalah proses dewatering. Oli bekas yang mengandung dikontakkan dengan $\mathrm{NaOH}$ untuk menetralkan senyawa asam yang ada pada campuran. Kemudian dialirkan ke pre flash tank untuk menghilangkan kandungan air yang ada dalam campuran. Uap air dan light component akan terlepas ke udara. Sedangkan campuran yang sudah terbebas dari air akan merDi kolom destilasi. Dari US Patent 6,712,954 tertanggal 30 Maret 2004 (German Patent DE 19852007 A1 tanggal 18 Mei 2000) ${ }^{[15]}$ telah ditentukan jika kondisi operasi kolom destilasi dibuat vakum dengan menggunakan ejector tekanan 0.05 bar dan temperatur $266{ }^{\circ} \mathrm{C}$. Uap yang dihasilakan merupakan fraksi diesel. Fraksi ini dikondensasikan dan ditampung di tangki penampung. Sedangkan produk bottom dari destilasi mengalir meunju thin film evaporator. Dari thin film evaporator, campuran akan diekstraksi menggunakan NMP sebagai pelarut dalam Rotating Disc Contactor. Pada ekstraktor ini, fraksi minyak yang mengandung banyak lube base oil akan terpisah dengan fraksi aromatis. Minyak hasil ekstraksi selanjutnya didestilasi untuk memisahkan NMP yang.terkandung. NMP hasil distilasi selanjutnya akan diresirkulasi untu dipakai kembali pada proses ekstraksi. Diagram blok untuk proses ekstraksi solvent menggunakan NMP ini adalah sebagai berikut.

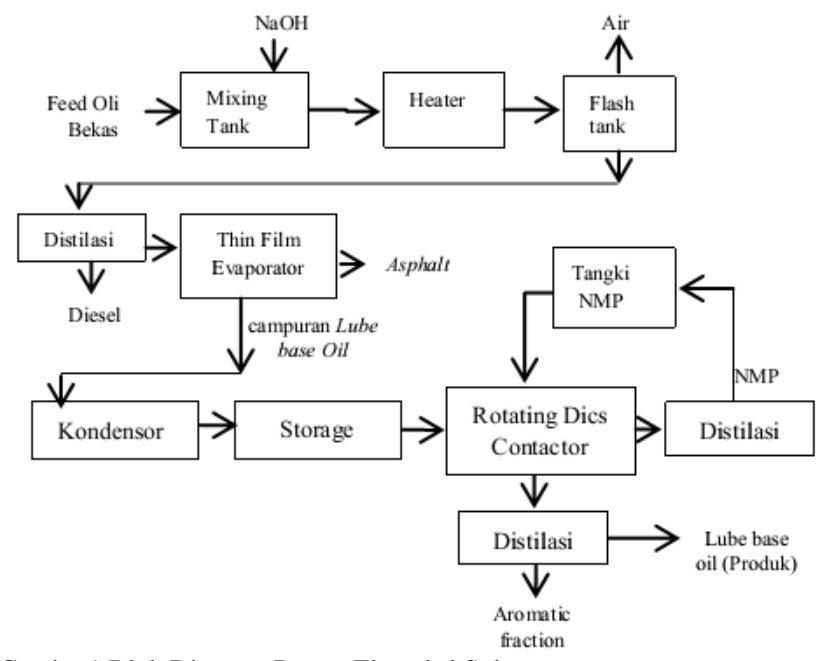

Gambar1.Blok Diagram Proses Ekstraksi Solvent

\section{Dewatering Unit}

Oli bekas yang ditampung pada tangki penampung (F114) dialirkan menuju mixer (M116) untuk dilakukan pencampuran dengan $\mathrm{NaOH}$ dari tangki penampung (F112). Dari mixer, campuran dialirkan menuju ke heater (E111) untuk dipanaskan dari suhu $30^{\circ} \mathrm{C}$ ke $130^{\circ} \mathrm{C}$ dan dialirkan ke pre flash tank (H110) untuk menghilangkan kandungan air yang ada dalam campuran. Uap air dan light component akan terlepas ke udara. Sedangkan campuran yang sudah terbebas dari air akan menuju kolom destilasi. Kondisi operasi kolom destilasi dibuat vakum dengan menggunakan ejector (G222) tekanan 0.05 bar dan temperatur $266^{\circ} \mathrm{C}$. Uap yang dihasilakan merupakan fraksi diesel. Fraksi ini dikondensasikan dan ditampung di tangki penampung (F221). Sedangkan produk bottom dari destilasi mengalir meunju thin film evaporator (V210).

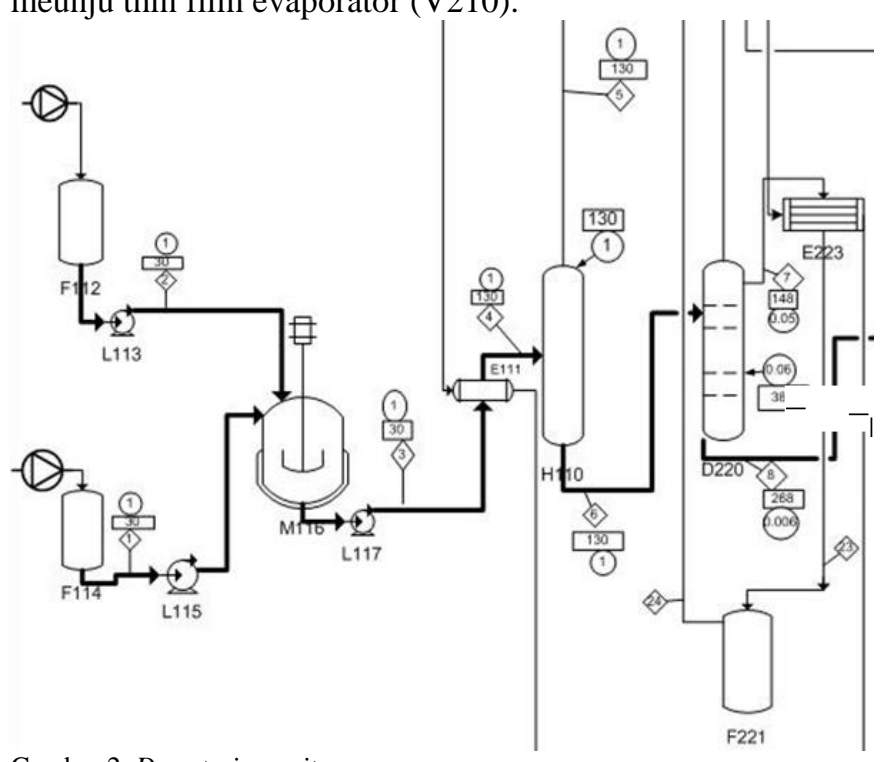

Gambar 2. Dewatering unit

\section{Sludge Removal Unit}

Thin Film Evaporator dalam kondisi vakum, tekanan 0.003 bar dan temperatur $385^{\circ} \mathrm{C}^{[15]}$. Fraksi yang mengandung banyak lube oil akan teruapkan dan dikondensasi. Sedangkan residu dari (V210) berupa fraksi unsaturated yang dapat diolah menjadi asphalt. Fraksi lube oil yang telah dikondensasi kemudian ditampung di tangki (F311). Dilakukan penampungan, karena terdapat perbedaan fase pada proses perubahan fase dari uap ke cair.

\section{Proses Ekstraksi dan Resirkulasi Pelarut}

Dari tangki (F311), fraksi campuran diumpankan ke rotating disc contactor dengan suhu operasi $80^{\circ} \mathrm{C}$. disisi lain Solven NMP dari tangki (F313) diumpankan ke ekstraktor. Ekstraksi dilakukan secara kontinyu.Pengumpanana dilakukan secara countercurrent. Fraksi yang kaya lube base oil keluar dari bagian atas kolom ekstraksi, dipompa menuju kolom destilasi (D410) dengan kondisi operasi $202^{\circ} \mathrm{C}$. Destilat berupa pelarut yang telah dikondensasikan pada temperatur $80{ }^{\circ} \mathrm{C}$ dan dialirkan menuju tangki penampung solven (F313). Solven ini akan diresirkulasi lagi. Kehilangan solven sangat mungkin terjadi pada proses ini, sehingga diperlukan makeup pelarut. Bottom produk dari kolom destilasi (D410) berupa produk utama lube base oil yang akan ditampung di tangki (F414). Bagian bawah ekstraktor yang berupa campuran aromatis, lube oil dan pelarut diumpankan ke kolom distilasi (D420) untuk memisahkan pelarut dengan fraksi minyaknya. Uap yang mengandung banyak pelarut akan keluar dari bagaian atas kolom, lalu dikondensasi dan megalir menuju tangki penampung solven (F313). Sedangkan bagian bottom kolom (D420) merupakan fraksi yang banyak mengandung fraksi oil dan aromatis. Produk ini ditampung di tangki (F423). 


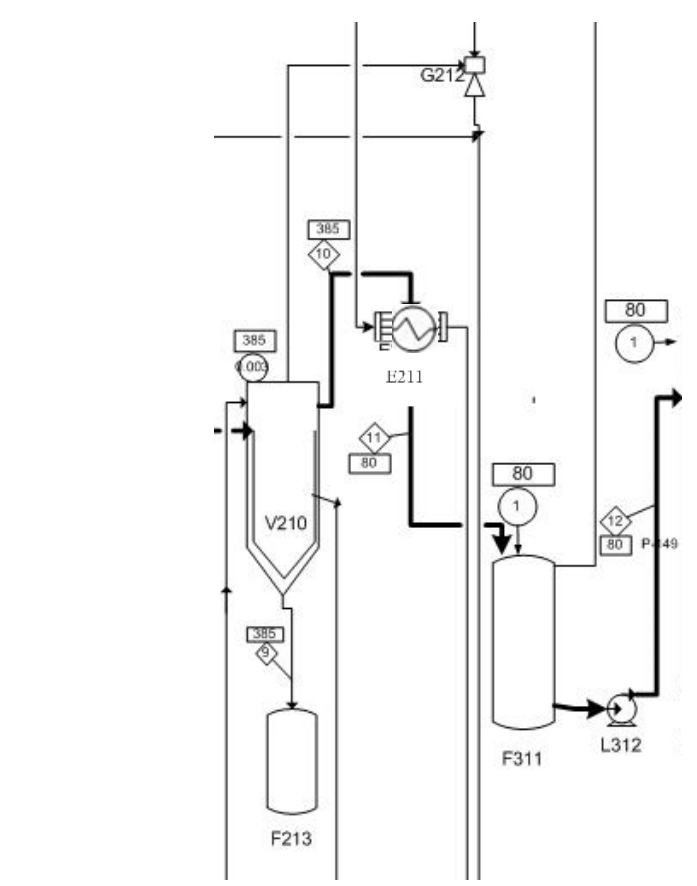

Gambar 3. Sludge removal unit

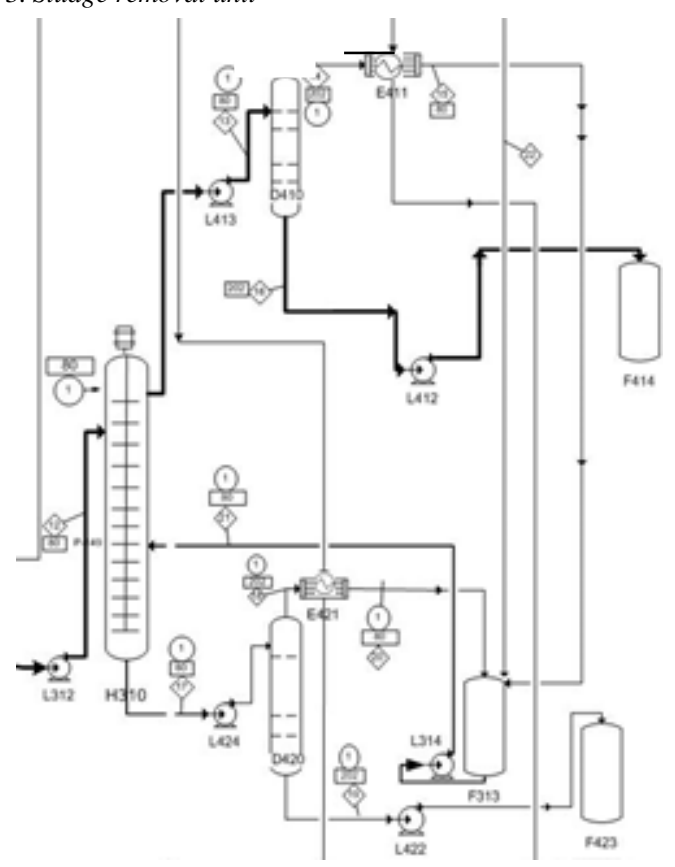

Gambar 4. Proses Ekstraksi dan Resirkulasi Pelarut

4. Spesifikasi produk

Dari proses pengolahan oli bekas menjadi lube base oil dengan proses ekstraksi solvent dilakukan perhitungan neraca massa pada setiap alat dan dihasilkan produk dengan spesifikasi sebagai berikut:

Tabel 4. Spesifikasi Produk

\begin{tabular}{lrr}
\hline \hline Komponen & Massa (kg/jam) & Fraksi (\%) \\
\hline Lube Base oil & 3469,64 & 99,8 \\
N-Methyl-2-pyrrolidone & 6.61 & 0,19 \\
Sulfur & 0,37 & 0,01 \\
Total & 3476,62 & 100 \\
\hline \hline
\end{tabular}

Pendirian suatu pabrik. Dengan analisa ekonomi dapat dilihat pabrik tersebut layak atau tidak untuk didirikan. Faktor-faktor yang perlu dipertimbangkan dalam penentuan untung rugi dalam mendirikan pabrik lube base oil adalah ${ }^{[12]}$ :

1. Laju pengembalian modal (rate of return).

2. Waktu pengembalian modal (pay out time).

3. Titik impas (break event point).

4. Interest rate of return (IRR).

Untuk menentukan faktor-faktor di atas terlebih dahulu perlu diketahui :

1. Total capital investment (TCI)

Total capital investment diartikan sebagai jumlah modal yang diperlukan untuk mendirikan suatu pabrik mulai dari awal sampai pabrik selesai dibangun dan siap beroperasi.

Total capital investment dibagi atas dua bagian, yaitu :

a) Fixed Capital Investment (FCI)

b) Working Capital Investment (WCI)

c) Total Production Cost (TPC)

Total production cost (total biaya produksi) terdiri dari Manufacturing Cost (Biaya Produksi).

Manufacturing cost adalah biaya yang dikeluarkan oleh pabrik yang berhubungan dengan operasi produksi dan peralatan proses yang terdiri dari :

a. Direct Production Cost (biaya produksi langsung)

b. Fixed Charges (biaya tetap)

c. Plant Overhead Cost (biaya tambahan pabrik

2. General Expenses (Biaya Umum)

Adalah biaya-biaya umum yang dikeluarkan untuk menunjang operasi pabrik, yang meliputi biaya administrasi, biaya pemasaran dan distribusi, biaya penelitian dan pengembangan (research dan development) serta pajak pendapatan.

\section{Analisa Profitability}

Dalam analisa ini digunakan beberapa asumsi, yaitu umur pabrik 10 tahun dengan kapasitas produksi masing-masing adalah :

1. Tahun pertama $65 \%$,

2. Tahun kedua $85 \%$,

3. Tahun ketiga sampai ke limabelas $100 \%$,

4. Pajak pendapatan $15 \%$ dari laba kotor.

\section{Analisa Ekonomi}


Tabel 5. Hasil Perhitungan Analisa Ekonomi

\begin{tabular}{|c|c|c|c|}
\hline \multirow{2}{*}{$\begin{array}{c}\text { No } \\
1\end{array}$} & \multirow{2}{*}{$\begin{array}{l}\text { Keterangan } \\
\text { Biaya Tetap }(\mathrm{FC})\end{array}$} & \multicolumn{2}{|c|}{ Jumlah (Rp) } \\
\hline & & $\mathrm{Rp}$ & 20.602.751.505 \\
\hline \multirow[t]{5}{*}{2} & Biaya Variabel (VC) & & \\
\hline & - Bahan baku & $\mathrm{Rp}$ & 162.417.415.281 \\
\hline & - Utilitas & $\mathrm{Rp}$ & 52.102 .362 .721 \\
\hline & - Royalty & $\mathrm{Rp}$ & 2.605 .118 .136 \\
\hline & Total Biaya Variabel (VC) & $\mathrm{Rp}$ & 217.124.896.137 \\
\hline \multirow[t]{9}{*}{3} & Biaya Semivariabel (SVC) & & \\
\hline & - Gaji karyawan & $\mathrm{Rp}$ & 11.502 .000 .000 \\
\hline & - Pengawasan & $\mathrm{Rp}$ & 2.605.118.136 \\
\hline & - Pemeliharaan dan perbaikan & $\mathrm{Rp}$ & 3.648 .403 .912 \\
\hline & - Operating Supplies & $\mathrm{Rp}$ & 3.648 .403 .912 \\
\hline & - Laboratorium & $\mathrm{Rp}$ & 230.040 .000 \\
\hline & - Pengeluaran umum & $\mathrm{Rp}$ & 15.630 .708 .816 \\
\hline & - Plant Overhead Cost & $\mathrm{Rp}$ & 13.025 .590 .680 \\
\hline & Total Biaya Semivariabel (SVC) & & 50.290 .265 .457 \\
\hline 4 & Total Penjualan (S) & $\mathrm{Rp}$ & 408.467.999.516 \\
\hline
\end{tabular}

BEP dapt dihitung menggunakan persamaan ${ }^{[12]}$ :

$$
\mathrm{BEP}=\frac{\mathrm{FC}+\mathrm{SVC}}{\mathrm{S}-\mathrm{VC}} \times 100 \%
$$

Dari hasil perhitungan didapatkan nilai BEP sebesar 22,86\%.

Hasil-hasil perhitungan analisa ekonomi yang diperoleh pada Tabel 2adalah sebagai berikut :

1. Total modal investasi (TCI) Rp 85.844.797.937

2. Total biaya produksi (TPC) Rp 260.511.813.603

3. Hasil penjualan per tahun Rp 408.467.999.516

4. Internal Rate of Return sebesar $46,7 \%$

5. Pay out time selama 2,74 tahun

6. Break even point sebesar $22,86 \%$

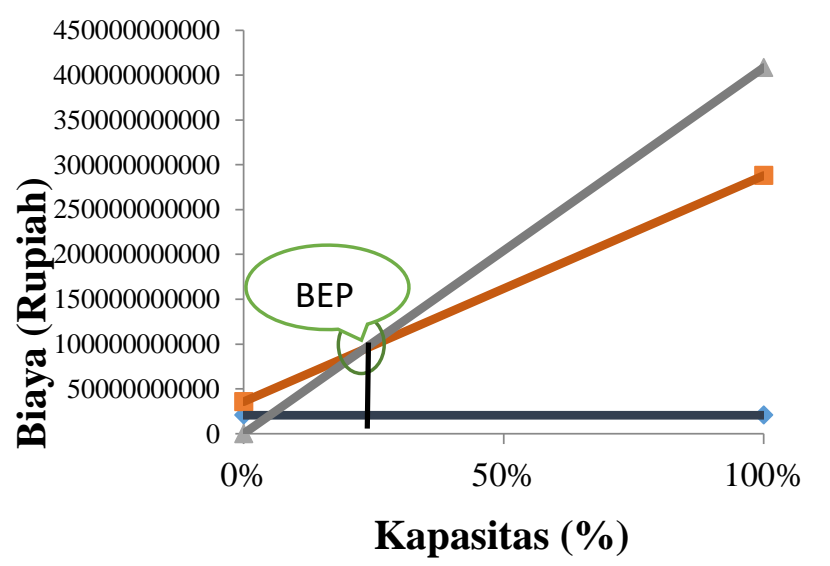

$\longrightarrow$ Biaya Tetap $\longrightarrow$ Pengeluaran Total $\longrightarrow$ Penjualan Total

Gambar 6. Grafik Break Even Point (BEP)

\section{KESIMPULAN/RINGKASAN}

Pabrik sodium karbonat ini direncanakan akan didirikan di Kabupaten Cilegon, Propinsi Banten. Pabrik direncanakan beroperasi secara kontinyu 24 jam selama 330 hari pertahun operasi dengan perencanaan sebagai berikut dengan kapasitas produksi $30700 \mathrm{~kL} / \mathrm{tahun}$ dan beroperasi dengan proses ekstraksi solvent. Solvent yang digunakan adalah N-Methyl Pirrolidone (NMP). Oli bekas dikontakkan dengan $\mathrm{NaOH}$ untuk menetralkan senyawa asam yang ada pada campuran. Kemudian dialirkan ke pre flash tank untuk menghilangkan kandungan air yang ada dalam campuran. Uap air dan light component akan terlepas ke udara. Sedangkan campuran yang sudah terbebas dari air akan menuju kolom destilasi. Dari US Patent 6,712,954 tertanggal 30 Maret 2004 (German Patent DE 19852007 A1 tanggal 18 Mei 2000) telah ditentukan jika kondisi operasi kolom destilasi dibuat vakum dengan menggunakan ejector tekanan 0.05 bar dan temperatur $266^{\circ} \mathrm{C}$. Uap yang dihasilakan merupakan fraksi diesel. Fraksi ini dikondensasikan dan ditampung di tangki penampung. Sedangkan produk bottom dari destilasi mengalir meunju thin film evaporator. Dari thin film evaporator, campuran akan diekstraksi menggunakan NMP sebagai pelarut dalam Rotating Disc Contactor. Pada ekstraktor ini, fraksi minyak yang mengandung banyak lube base oil akan terpisah dengan fraksi aromatis. Minyak hasil ekstraksi selanjutnya didestilasi untuk memisahkan NMP yang.terkandung. NMP hasil distilasi selanjutnya akan diresirkulasi untu dipakai kembali pada proses ekstraksi. Lube oil yang di hasilkan dalam pradesain pabrik ini dengan kadar 99,8\%.Pendirian pabrik lube base oil memerlukan biaya investasi modal tetap (fixed capital) sebesar Rp. 20.602.751.505, modal kerja (working capital) Rp. 12.876.719.691, investasi total Rp. 85.844.797.937, Biaya produksi per tahun Rp.260.511.813.603, dan hasil penjualan pertahun Rp.408.467.999.516. Dari analisa ekonomi didapatkan BEP 22,86\%, POT sesudah pajak 2,74 tahun.Dari segi teknik dan ekonomi, pabrik soda abu ini layak untuk didirikan.

\section{DAFTAR PUSTAKA}

[1] Badan Pusat Statistik

[2] Brownell, danYoung. (1959) "Process Equipment Design". New York: John Wiley \& Sons

[3] Couper, james R, W.Roy Penney, dan Stanley M.Walas. (2010). "Chemical process Equipment : Selection and Design" 2nd edition. Oxford: Elseiver,Inc.

[4] Geankoplis, Christie J.(1993).Transport Process and Unit Operation,3rd Edition. New Jersey: Prentice Hall.

[5] Himmeblau, D.M. (1982) "Basic Principles and Calculation in Chemical Engineering", 4th Edition. New Jersey: Prentice Hall.

[6] Kern, Donald Q. (1965) "Process Heat Transfer". Singapore: McGraw Hill.

[7] Ludwig, Ernest E. (1999). "Applied Process Design for Chemical and Petrochemical Plants" 3rd Edition. United States: ButterworthHeinemann.

[8] McCabe, Warren 1, Julian C Smith, dan Peter harriot. (1993)."Unit Operation of Chemical Engineering" 5th edition. New York: McGrawHill, Inc.

[9] Perry, R.H dan C.H. Chilton.(1999).."Chemical Engineers' Handbook" 7th Edition. New York: McGraw Hill Book Co.

[10] PETDER.Co.PETDR-Petroleum Industry Association.Selection of the Most Appropriate Technology for Waste Mineral Oil Refining Project Technical Research Report 2012.(2012) 
[11] Peters, Max S., Klaus D. Timmerhaus, and Ronald E. West, "Plant Design and Economics for Chemical Engineers", $5^{\text {th }}$ edition, McGraw-Hill BookCompany, Boston, 2003.

[12] Sinnot, R.K. (2005). "Coulson and Richardson Chemical Engineering" 4th Edition. Oxford: Elseiver,Inc.

[13] Smith, J.M, Van Ness, H.C dan M.M Abbot.(2001)."Chemical Engineering Thermodinamic". 6th edition, New York: McGraw Hill Company

[14] Ulrich, G.D. (1984). “A Guide to Chemical Engineering Process Design and Economics". New Jersey: John Willey \& Sons.

[15] US Patent 6,712,954 .MRD

[16] www.FactfishIndonesia.com (diakses pada 10 Nopember 2015, pukul 08.00)

[17] www.matche.com (diakses pada, 12 Januari 2016, pukul 20.00)

[18] www.ptwgi (diakses pada, 12 Nopemberi 2015, pukul 17.00)

[19] www.statler.wvu.edu (diakses pada 10 Oktober 2015, pukul 11.00) 